Очевидно, монография значительно выиграла бы, если бы автор широко использовал судебную и арбитражную практику, как международную, так и внутригосударственную. Пока эта практика представлена в исследовании очень слабо.

Разумеется, сказанное никак не умаляет достоинств монографии Л.Х. Мингазова. Это новаторская работа по одной из сложных и, пожалуй, самых актуальных проблем современного международного права. Автор вносит в ее научную разработку ощутимый вклад, который и позволяет охарактеризовать его работу как полезное исследование эффективности международно-правовых норм.

\title{
ЦЕННОЕ ПОСОБИЕ ДЛЯ ВСЕХ, ИМЕЮЩИХ ОТНОШЕНИЕ К ПРАВУ МЕЖДУНАРОДНОЙ ТОРГОВЛИ
}

\section{А.И. Муранов}

(Twenty Years of International Sales Law Under the CISG (The UN Convention on Contracts for the International Sale of Goods). International Bibliography and Case Law Digest (1980-2000). Edited by

Michael R. Will. - Kluwer Law International, 2000, 754 c.).

Любому исследователю, связанному с изучением права международной торговли, очень хорошо известно, какими темпами увеличивается объем публикуемой научной и прикладной информации в данной сфере. В итоге ориентироваться в этом море информации, причем на различных языках, достаточно сложно. Еще большие трудности испытывают исследователи и практики в России, где доступ не только к иностранным книжным новинкам, но даже и к журналам весьма затруднен по всем известным объективным причинам. В такой ситуации помогающим решить многие проблемы является обращение к специальным изданиям библиографического и справочного характера, являющимся итогом долгой и кропотливой рабо-

\footnotetext{
• К. ю. н., ст. преподаватель кафедры международного частного и гражданского права МГИМО (У) МИД России.
} 
ты. Значимость таких трудов трудно переоценить: библиография и систематизация данных являются теми столпами, без которых развитие науки невозможно.

В свете сказанного опубликование указанной выше книги является весьма примечательным событием. Конечно же, данный труд посвящен не всему праву международной торговли, а только его части, но части основной и очень важной - Конвенции ООН о договорах международной купли-продажи товаров, разработанной Комиссией ООН по праву международной торговли (ЮНСИТРАЛ) и принятой на конференции ООН в Вене в 1980 г. Следует отметить, что выход рассматриваемой книги в свет был приурочен к 20-летию существования Конвенции и явился одним из событий, посвященных данному юбилею. Юбилей действительно знаменательный: Конвенция выступает в роли уникального правового акта, до сих пор не имевшего аналогов в мировой истории правотворчества. Она вводит единообразное материально-правовое регулирование международных сделок купли-продажи товаров и является основанной на компромиссе подходов романо-германской и англо-американской правовых систем. Конвенция пользуется поистине всемирным признанием: на 1 октября 1999 г. она действует для 56 государств (всего же к ней присоединилось 57 государств), общая доля которых в мировой торговле составляет более двух третей, и их число продолжает увеличиваться. Принятие Конвенции и ее всемирный успех стали теми событиями, которые позволяют говорить о том, что хотя широкомасштабная унификация регулирования международного торгового оборота и является задачей далекого будущего, однако оказывается делом вполне реальным, положительные последствия которого действительно стоят того, чтобы им заниматься.

Рассматриваемый труд, изданный под редакцией профессора Университета Женевы М. Уилла, известного специалиста в сфере частного права и права международной торговли, - очень серьезный шаг на таком пути. В данной книге поставлены и успешно решены две задачи.

Во-первых, на 438 страницах приводится очень полная библиография работ, посвященных Конвенции ООН о договорах международной купли-продажи товаров. При этом учтены работы, выпущенные в нескольких десятках государств на различных языках, в том числе и на русском. Библиографический указатель снабжен именным и географическим указателями, наличие которых делает поиск нужной информации весьма легким. 
Во второй части в систематизированном виде содержится информация за 1981-1999 гг. о примерно 600 решениях национальных судов и международных коммерческих арбитражей, при вынесении которых применялась или упоминалась Конвенция. Приводятся следующие данные: орган, вынесший решение; дата и номер решения; государство, из которого поставлялся товар, и государство, в которое он поступил; вид товара; цена и валюта сделки; статьи Конвенции, которые были применены или на которые была сделана ссылка; данные о публикации решения, публикации его переводов, его изложений и комментариев к нему (однако некоторые такие данные иногда отсутствуют по объективным причинам). Данный указатель снабжен таблицей, в которой показано количество решений, вынесенных государственными судами различных стран в различные годы, и количество решений, вынесенных в различные годы третейскими судами. Приводятся также данные о судебных решениях, сгруппированные по странам, и об арбитражных решениях, сгруппированные по конкретным третейским судам (любопытно отметить, что количество указаний на решения Международного коммерческого арбитражного суда при Торгово-промышленной палате РФ занимает более половины от общего числа таких указаний). В итоге поиск нужной информации занимает буквально минуты.

Необходимо отметить, что профессор М. Уилл уже в течение многих лет собирает информацию о судебных и арбитражных решениях по Конвенции ООН о договорах международной куплипродажи товаров и является в данной сфере признанным экспертом. Еще в 1994 г. в Женеве им была опубликована книга «CISG - The First Hundred Decisions», и вслед за этим им было выпущено еще 7 переработанных ее изданий, так что в последнем из них, появившемся в 1999 г., фигурирует уже около 555 ссылок на решения. Таким образом, рассматриваемая книга является уже девятым по счету изданием указаний на судебные и арбитражные решения по Конвенции ООН о договорах международной купли-продажи товаров.

Следует упомянуть и о том, что в книгу вошла информация из баз данных по этой Конвенции, ведущихся ЮНСИТРАЛ («Прецедентное право по текстам ЮНСИТРАЛ» - « ППТЮ» или «СLOUТ» в английской транскрипции), Школой права Университета Пейс (Нью-Йорк, США), правовым факультетом Университета Фрайбурга (Германия), ЮНИДРУА (система UNILEX).

Держа в руках работу профессора М. Уилла и листая ее, понимаешь, какой колоссальный труд был им проделан для того, чтобы 
составить этот удобный в обращении указатель библиографии и судебных решений по Конвенции. Конечно же, в этом труде также принимали участие, собирали и предоставляли информацию многие другие лица - библиотекари, ученые и судьи из разных стран, ассистенты и прочие.

В данную книгу вошли не все указания на русскоязычные работы или решения российских государственных и третейских судов, связанные с Конвенцией ООН о договорах международной куплипродажи товаров. Однако это замечание должно быть направлено не редактору, а представителям российского права, которые делают пока еще не все, что в их силах, для того, чтобы остальной мир имел более ясное представление о месте и роли Конвенции в России. А то, что такой интерес присутствует и, более того, то, что он очень велик, - сомнению не подлежит. Однако есть надежда, что вскоре после того момента, когда данная рецензия будет опубликована, в Интернете уже будет функционировать русскоязычная база данных по Конвенции (наряду с базами данных из США, Германии, Франции, Италии, Японии, Испании, Бразилин, Изранля, Финляндии), обнаружить которую можно будет при помощи сайта http://www.cisg.law.pace.edu. Там же могут быть найдены и все вышеупомянутые базы, равно как и множество другой информации о Конвенции. Для всех заинтересованных лиц нельзя не упомянуть отдельно и о сайте ЮНСИТРАЛ - http://www.un.or.at/uncitral.

Книга профессора М. Уилла может служить не только образцом для подобного вида трудов, но таюже и напоминанием представителям российского права о том, что в России дела с юридической библиографией и систематизацией информации о судебных решениях по тем или иным темам обстоят далеко не лучшим образом. И речь идет не только о таких еще во многом «экзотических» в России сферах регулирования, как международное частное право и право международной торговли, - даже в сфере конституционного и уголовного права, не говоря уже о частноправовой области, дела обстоят не так, как хотелось бы. И данное обстоятельство можно без преувеличения назвать весьма значительным препятствием, стоящим на пути серьезного развития российского правоведения. 